\title{
Tokar M. DEVELOPMENT OF BLIND FRAME SYNCHRONIZATION FOR TRANSFER SYSTEM WITH DIFFERENTIAL SPACE-TIME BLOCK CODING
}

Об’єктом дослідження даної роботи є методи і алгоритми кадрової синхронізації, використовувані в системах багатоантенного радіозв'язку (Multiple Input Multiple Output - MIMO). Реалізація систем радіозв'язку $i$, зокрема МІМО, має на увазі забезпечення в демодуляторі синхронізачії по фазі опорної несучої і за часом прочесів обробки сигналів. Синхронізащія за часом розділяється на символьну $і$ кадрову синхронізащї. Що стосується синхронізащї опорної несучої і символьної синхронізащї, то щі види синхронізачї забезпечуються традиційними методами і в даній роботі не розглядаються. Кадрова синхронізація в переважній більшості випадків забезпечується застосуванням пілот-сигналів (синхрослів). За своєю суттю вони є маркерами і періодично вбудовуються в потік даних для позначення початку чергового нового блоку даних. Ресурси системи передачі, що витрачаються на передачу пілот-сигналів, не задіюються для передачі інформацї користувача, через що погіршується ефективність використання частотно-тимчасового ресурсу системи. У більш меншому обсязі існують так звані «сліпі» методи обробки сигналів, що грунтуються на властивостях надмірності переданого сигналу. Ці методи не мають недоліків від застосування пілот-сигналів і поділяються на методи оцінки стану каналу зв'язку, ідентифікацї сигналів і синхронізації. Виходячи з цього, такі методи представляють практичний інтерес.

У даній роботі пропонується спосіб кадрової синхронізації для демодулящї сигналів диференціального просторово-часового блокового кодування при застосуванні технології МІМО. Алгоритм синхронізацї не вимагає використання преамбул і синхрослів, що забезпечує ефективне використання частотно-тимчасового ресурсу. Аналіз структури алгоритму і результати моделювання показують його працездатність при низьких відносинах сигнал/шум в системі передачі. Алгоритм не вимагає знань про стан каналу зв'язку, має малу обчислювальну складність, в порівнянні з існуючими аналогами, i допускає реалізацію при різному числі передавальних і приймальних антен.

Ключові слова: система МІМО, кадрова синхронізація, пілот-сигнал, частотно-часовий ресурс, сліпий метод обробки сигналів, просторово-часова надмірність сигналу.

\section{Introduction}

This work is a continuation of research on the development of a transmission method with differential space-time block coding (DSTBC) implemented using the Multiple Input Multiple Output (MIMO) technology [1].

To implement the method of transmission from the DSTBC in the demodulator, it is necessary to provide phase synchronization of the reference carrier, as well as time synchronization of signal processing processes [2, 3]. The time synchronization task is divided into two: symbolic (clock) synchronization and frame (block) synchronization. These two types of time synchronization are completely different in purpose and implementation. The task of symbol synchronization is to synchronize the clocks of the demodulator with the input stream of demodulated channel symbols so that each input symbol is processed in an appropriate time interval. The task of synchronizing frames (blocks) is to split the sequence of characters arriving at the decoder into blocks corresponding to the blocks at the output of the encoder. If the breakdown is not carried out correctly, decoding operations will be incorrect and restoration of transmitted characters becomes impossible.

As for synchronization of the reference carrier and symbol synchronization, these types of synchronization in demodulators of digital modulation signals are solved by traditional methods $[4,5]$ and are not considered in this paper.

From literature it follows that in the vast majority of cases, frame synchronization is ensured by the use of pilot signals (sync words) (Reference Signal) [6, 7] signals a priori known in the demodulator that have certain characteristics and properties. At their core, they are markers and are periodically embedded in the data stream to indicate the beginning of another new data block. It is obvious that the resources of the transmission system spent on the transmission of pilot signals are not used directly for transmitting user information, as a result of which the efficiency of using the time-frequency 
resource of the transmission system is degraded. The literature also presents, but to a lesser extent, the so-called «blind» signal processing methods that do not require the transmission of special pilot signals, but are based on the properties of the transmitted information signal, in particular, using its redundancy $[6,8]$. These methods do not have the disadvantages created by the use of pilot signals, and are divided into methods for assessing the state of the communication channel, signal identification, and synchronization. Based on this, such methods are of practical interest.

There are works $[9,10]$ that describe the methods of «blind» frame synchronization for orthogonal space-time block coding (STBC). It should be noted that these methods:

- use the space-time redundancy of the transmitted signal (frames);

- applicable for STBC orthogonal systems with one and two receiving antennas;

- do not require knowledge of the state of the communication channel and the signal-to-noise ratio in the channel;

- provide a low ability to detect the boundaries of frame intervals in the communication channel with Rayleigh fading at high signal-to-noise ratios, as the authors themselves declare.

It should also be noted that only these two blind frame synchronization methods for STBC orthogonal systems are described in the literature, and synchronization methods for STBC differential orthogonal systems are not described.

Based on the foregoing, in order to ensure frame synchronization during demodulation of the DSTBC signals, it is decided to develop an effective frame synchronization algorithm based on this coding method without using pilot signals, which is the goal of this work. Thus, the subject of this research is the methods and algorithms for frame synchronization used in multi-antenna radio communication systems (MIMO).

\section{Methods of research}

Below is the synchronization algorithm for the demodulator of the DSTBC signals [1] in the MIMO scheme and. Since each channel symbol is transmitted twice during the DSTBC, the signal matrix can serve as an example:

$$
\mathbf{X}_{v}=\left[\begin{array}{cc}
x_{i} & -x_{i+1}^{*} \\
x_{i+1} & x_{i}^{*}
\end{array}\right]
$$

where $x_{i}^{*}$ - complex conjugation of the symbol $x_{i}$, it follows that the demodulated signal has a space-time redundancy, and it is possible to find a way to synchronize the working signal.

Table 1 shows four consecutive frames transmitted over a communication channel. Here $x_{i}$ - the channel symbols of the L-PSK signal.

Table 1

Symbol transmission table by differential space-time block coding

\begin{tabular}{|c|c|c|c|c|c|c|c|c|}
\hline Moment of time & $t$ & $t+1$ & $t+2$ & $t+3$ & $t+4$ & $t+5$ & $t+6$ & $t+7$ \\
\hline Antenna No. 1 & $x_{1}$ & $-x_{2}^{*}$ & $x_{3}$ & $-x_{4}^{*}$ & $x_{5}$ & $-x_{6}^{*}$ & $x_{7}$ & $-x_{8}$ \\
\hline Antenna No. 2 & $x_{2}$ & $x_{1}^{*}$ & $x_{4}$ & $x_{3}^{*}$ & $x_{6}$ & $x_{5}^{*}$ & $x_{8}$ & $x_{7}^{*}$ \\
\hline Frame number & \multicolumn{3}{|c|}{ frame 1 } & \multicolumn{1}{|c|}{ frame 2 } & \multicolumn{2}{c|}{ frame 3 } & \multicolumn{2}{c|}{ frame 4 } \\
\hline
\end{tabular}

If it is necessary to demodulate the information transmitted by frame $3-$

$$
\mathbf{X}_{3}=\left[\begin{array}{cc}
x_{5} & -x_{6}^{*} \\
x_{6} & x_{5}^{*}
\end{array}\right],
$$

then frame 2

$$
\mathbf{X}_{2}=\left[\begin{array}{cc}
x_{3} & -x_{4}^{*} \\
x_{4} & x_{3}^{*}
\end{array}\right]
$$

is required, which will be the reference. This happens when the frame synchronization is correct. Having analyzed the Table 1, two immediate cases can be assumed in which frame synchronization is not set correctly.

In the first case, let's have the following values of the reference and signal matrices:

$$
\mathbf{X}_{2 e r r_{-} l}=\left[\begin{array}{cc}
-x_{2}^{*} & x_{3} \\
x_{1}^{*} & x_{4}
\end{array}\right], \quad \mathbf{X}_{3 e r r_{-} l}=\left[\begin{array}{cc}
-x_{4}^{*} & x_{5} \\
x_{3}^{*} & x_{6}
\end{array}\right] .
$$

In the second case, respectively:

$$
\mathbf{X}_{2 e r r_{-} r}=\left[\begin{array}{cc}
-x_{4}^{*} & x_{5} \\
x_{3}^{*} & x_{6}
\end{array}\right], \quad \mathbf{X}_{3 e r r_{-} r}=\left[\begin{array}{cc}
-x_{6}^{*} & x_{7} \\
x_{5}^{*} & x_{8}
\end{array}\right] .
$$

Thus, let's obtain three possible states, in one of which the frame synchronization is set correctly, and in the other two it is not true. Hypotheses on these conditions can be respectively arbitrarily called: «early», «right» and «late».

Let's consider the demodulation of characters in the case of a hypothesis - «right». The samples of the signals received by the receiving antennas (frame 2 and frame 3 ), at the corresponding time points, can be written as:

$$
\begin{aligned}
& {\left[\begin{array}{ll}
y_{1}^{(t+2)} & y_{2}^{(t+2)} \\
y_{1}^{(t+3)} & y_{2}^{(t+3)}
\end{array}\right]=} \\
& =\mathbf{X}_{2}^{T}\left[\begin{array}{ll}
h_{11} & h_{12} \\
h_{21} & h_{22}
\end{array}\right]+\left[\begin{array}{ll}
w_{1}^{(t+2)} & w_{2}^{(t+2)} \\
w_{1}^{(t+3)} & w_{2}^{(t+3)}
\end{array}\right] \rightarrow \mathbf{Y}_{2}=\mathbf{X}_{2}^{T} \mathbf{H}+\mathbf{W}_{2},
\end{aligned}
$$

$$
\begin{aligned}
& {\left[\begin{array}{ll}
y_{1}^{(t+4)} & y_{2}^{(t+4)} \\
y_{1}^{(t+5)} & y_{2}^{(t+5)}
\end{array}\right]=} \\
& =\mathbf{X}_{3}^{T} \mathbf{H}+\left[\begin{array}{ll}
w_{1}^{(t+4)} & w_{2}^{(t+4)} \\
w_{1}^{(t+5)} & w_{2}^{(t+5)}
\end{array}\right] \rightarrow \mathbf{Y}_{3}=\mathbf{X}_{3}^{T} \mathbf{H}+\mathbf{W}_{3},
\end{aligned}
$$

where, for example, $y_{1}^{(t+2)}-$ the count taken at the time $t+2$ (upper index) by the first antenna (lower index); $h_{m, n}-$ complex transmission channel transmission coefficients from the $m$-th transmitting antenna to the $n$-th receiving antenna, which are uncorrelated complex Gaussian random variables at $h_{m, n} \sim C N(0,1) ; w_{n}^{(t)}-$ complex coefficients of additive white Gaussian noise with $w_{n}^{(t)} \sim C N\left(0, \sigma^{2}\right)$ and dispersion $\sigma^{2}$.

Let's believe that the condition $T_{0} \gg T_{s}$ is satisfied, where $T_{0}$ - the coherence time, and $T_{s}-$ the duration of the channel symbol - hence, the matrix of channel coefficients $\mathbf{H}$ during $T_{0}$ is relatively constant [1]. In this case, the restored values of the differential coefficients transmitted by frame 3 are determined as: 


$$
\begin{aligned}
& {\left[\begin{array}{l}
\hat{R}_{1} \\
\hat{R}_{2}
\end{array}\right]=} \\
& =\frac{\left[\begin{array}{cc}
\left(y_{1}^{(t+2)}\right)^{*} & y_{1}^{(t+3)} \\
\left(y_{1}^{(t+3)}\right)^{*} & -y_{1}^{(t+2)}
\end{array}\right]\left[\begin{array}{c}
y_{1}^{(t+4)} \\
\left(y_{1}^{(t+5)}\right)^{*}
\end{array}\right]^{*}\left[\begin{array}{cc}
\left(y_{2}^{(t+2)}\right)^{*} & y_{2}^{(t+3)} \\
\left(y_{2}^{(t+3)}\right)^{*} & -y_{2}^{(t+2)}
\end{array}\right]\left[\begin{array}{c}
y_{2}^{(t+4)} \\
\left(y_{2}^{(t+5)}\right)^{*}
\end{array}\right]}{\left|y_{1}^{(t+2)}\right|^{2}+\left|y_{1}^{(t+3)}\right|^{2}+\left|y_{2}^{(t+2)}\right|^{2}+\left|y_{2}^{(t+3)}\right|^{2}}
\end{aligned}
$$

If to consider the $2 \times 4$ MIMO scheme, then formulas (1)-(3) respectively will take the following form:

$$
\begin{aligned}
& {\left[\begin{array}{llll}
y_{1}^{(t+2)} & y_{2}^{(t+2)} & y_{3}^{(t+2)} & y_{4}^{(t+2)} \\
y_{1}^{(t+3)} & y_{2}^{(t+3)} & y_{3}^{(t+3)} & y_{4}^{(t+3)}
\end{array}\right]=} \\
& =\mathbf{X}_{2}^{T} \mathbf{H}+\left[\begin{array}{cccc}
w_{1}^{(t+2)} & w_{2}^{(t+2)} & w_{3}^{(t+2)} & w_{4}^{(t+2)} \\
w_{1}^{(t+3)} & w_{2}^{(t+3)} & w_{3}^{(t+3)} & w_{4}^{(t+3)}
\end{array}\right] \rightarrow \mathbf{Y}_{2}=\mathbf{X}_{2}^{T} \mathbf{H}+\mathbf{W}_{2}, \\
& {\left[\begin{array}{llll}
y_{1}^{(t+4)} & y_{2}^{(t+4)} & y_{3}^{(t+4)} & y_{4}^{(t+4)} \\
y_{1}^{(t+5)} & y_{2}^{(t+5)} & y_{3}^{(t+5)} & y_{4}^{(t+5)}
\end{array}\right]=} \\
& =\mathbf{X}_{3}^{T} \mathbf{H}+\left[\begin{array}{cccc}
w_{1}^{(t+4)} & w_{2}^{(t+4)} & w_{3}^{(t+4)} & w_{4}^{(t+4)} \\
w_{1}^{(t+5)} & w_{2}^{(t+5)} & w_{3}^{(t+5)} & w_{4}^{(t+5)}
\end{array}\right] \rightarrow \mathbf{Y}_{3}=\mathbf{X}_{3}^{T} \mathbf{H}+\mathbf{W}_{3}
\end{aligned}
$$

where $\mathbf{H}=\left[\begin{array}{llll}h_{11} & h_{12} & h_{13} & h_{14} \\ h_{21} & h_{22} & h_{23} & h_{24}\end{array}\right]$, and

$$
\left[\begin{array}{l}
\widehat{R}_{1} \\
\widehat{R}_{2}
\end{array}\right]=\frac{\sum_{n=1}^{4}\left(\left[\begin{array}{cc}
\left(y_{n}^{(t+2)}\right)^{*} & y_{n}^{(t+3)} \\
\left(y_{n}^{(t+3)}\right)^{*} & -y_{n}^{(t+2)}
\end{array}\right]\left[\begin{array}{c}
y_{n}^{(t+4)} \\
\left(y_{n}^{(t+5)}\right)^{*}
\end{array}\right]\right)}{\sum_{n=1}^{4}\left(\left|y_{n}^{(t+2)}\right|^{2}+\left|y_{n}^{\left(t+\left.3\right|^{2}\right.}\right|^{2}\right)} .
$$

After restoring the differential coefficients, by assessing the maximum likelihood, the minimum distance between the possible values of the vectors $\left(R_{1}, R_{2}\right)$, (from the set $\mathbf{R}_{\text {all }}$ [1]) and the reconstructed vector $\left(R_{1}, R_{2}\right)$ is determined:

$$
b_{\text {true }}^{(3)}=\arg \min _{j \in R_{\text {all }}}\left(\left|\left(R_{1}\right)_{j}-\widehat{R}_{1}\right|^{2}+\left|\left(R_{2}\right)_{j}-\widehat{R}_{2}\right|^{2}\right),
$$

where the superscript of the quantity $b_{\text {true }}^{(3)}$ denotes the number of the frame in relation to which the decision to synchronize. In the same way, one can calculate the values of the minimum distances $b_{\text {fasse } 1}^{(3)}$ and $b_{\text {fasse } 2}^{(3)}$ using the other two hypotheses.

An analysis of the matrices $\mathbf{X}_{2 e r r}$ and $\mathbf{X}_{3 e r}$ shows that each of them contains symbols $x_{i}$ once (for example, in: $\mathbf{X}_{2 e r r}:-x_{2}^{*}, x_{1}^{*}, x_{3}, x_{4}$ ), and also these matrices are not complex orthogonal forms (condition (2) in [1]). Given this, as well as the statistical independence and equiprobability of the transmitted symbols $x_{i}$, it should be concluded that when demodulating (in the estimates of the differential coefficients $\widehat{R}_{1}$ and $\widehat{R}_{2}$ ) there is no coherent accumulation of the transmitted symbols and they can be considered as readings from the implementation of some random process.

Consequently, the frame synchronization system of the DSTBC demodulator will analyze the three hypotheses outlined - «early», «right» and «late». The signal for choosing a particular hypothesis will be the minimum value of the sum of the accumulated values of the minimum distances for each hypothesis:

$$
B_{\text {fase1 }}=\sum_{k=1}^{K} b_{\text {false } 1}^{(k)}, \quad B_{\text {true }}=\sum_{k=1}^{K} b_{\text {true }}^{(k)} \text { and } \quad B_{\text {false } 2}=\sum_{k=1}^{K} b_{\text {false } 2}^{(k)} \text {, }
$$

where $K$ - the number of frames (blocks) of observation for deciding on the presence/absence of frame synchronization. As can be seen from the algorithm, these values are filtered (accumulation is performed). At each step, in order to correctly set the boundaries of the frames, a comparison is made between each other $B_{\text {false } 1}, B_{\text {true }}, B_{\text {false } 2}$, and a particular hypothesis is selected based on the minimum of these values.

\section{Research results and discussion}

The simulation was performed in the MATLAB software package using the Rayleigh channel of fading in the communication channel and observing the conditions for constant values of the channel coefficients $h_{m, n}$ during the coherence time $T_{0}$. The model consisted of two $(M=2)$ transmitting and several $(N=1 ; 2 ; 4)$ receiving antennas, using QPSK modulation and $K=10 ; 20 ; 30 ; 40 ; 50$. The input stream consisted of independent equally probable $5 \cdot 10^{7}$ bits of information, which was encoded using the DSTBC method [1] depending on the number of positions of the L-PSK signal and the number of transmitting antennas $M$, forming signal matrices $\mathbf{X}_{v}$ that were transmitted to the radio channel, as indicated in Table 1. On the receiving side, the values were calculated:

$$
\mathbb{B}_{\text {fasse }}=\sum_{d=1}^{D} B_{\text {false } 1}^{(d)}, \quad \mathbb{B}_{\text {true }}=\sum_{d=1}^{D} B_{\text {true }}^{(d)} \text { and } \mathbb{B}_{\text {false } 2}=\sum_{d=1}^{D} B_{\text {fasse } 2}^{(d)},
$$

where $D$ - the number of transmitted frame blocks, each of which consists of $K$ frames. Moreover, for each of the three values $B_{\text {false }}, B_{\text {true }}, B_{\text {false } 2}$ a decision was made on the presence/absence of frame synchronization of a particular frame unit $d$. For example, if the number of information bits is $5 \cdot 10^{7}, M=2$, QPSK modulation, and $K=20$, the value is $D=2.5 \cdot 10^{6}$. The simulation results are presented in Fig. 1, 2 in the form of dependences of the probability of the exit from synchronism (loss of synchronism) $P_{\text {er sinch }}=D_{\text {erorr }} / D$, where $D_{\text {erorr }}$ - the number of received frame blocks with no frame synchronization, on the signal-to-noise ratio in the system (SNR).

Based on the analysis of the algorithm and the simulation results, the following should be noted:

1) developed synchronization algorithm for analysis and decision making requires a significantly smaller number of frames $(10-40)$ than the methods presented in $[9,10]-$ 513-4097 frames are required;

2) description of the developed algorithm can easily be expanded for the cases of 4 transmitting and 8 receiving antennas in accordance with the DSTBC method (this extension of the algorithm was not included in the paper); also, the algorithm, if necessary, can be expanded for cases of delay or advancing relative to the beginning of the frame for a time or more;

3) this synchronization algorithm is not a separate structural part (such as methods $[9,10]$ ) in the implementation of the DSTBC method. At its core, the algorithm is based on the DSTBC method and supplements it, extracting some data for further calculation and ensuring the decision on synchronization (formulas (3), (6)-(7) are part of the DSTBC method). In this regard, this synchronization algorithm is much less computationally complex than previously proposed; 

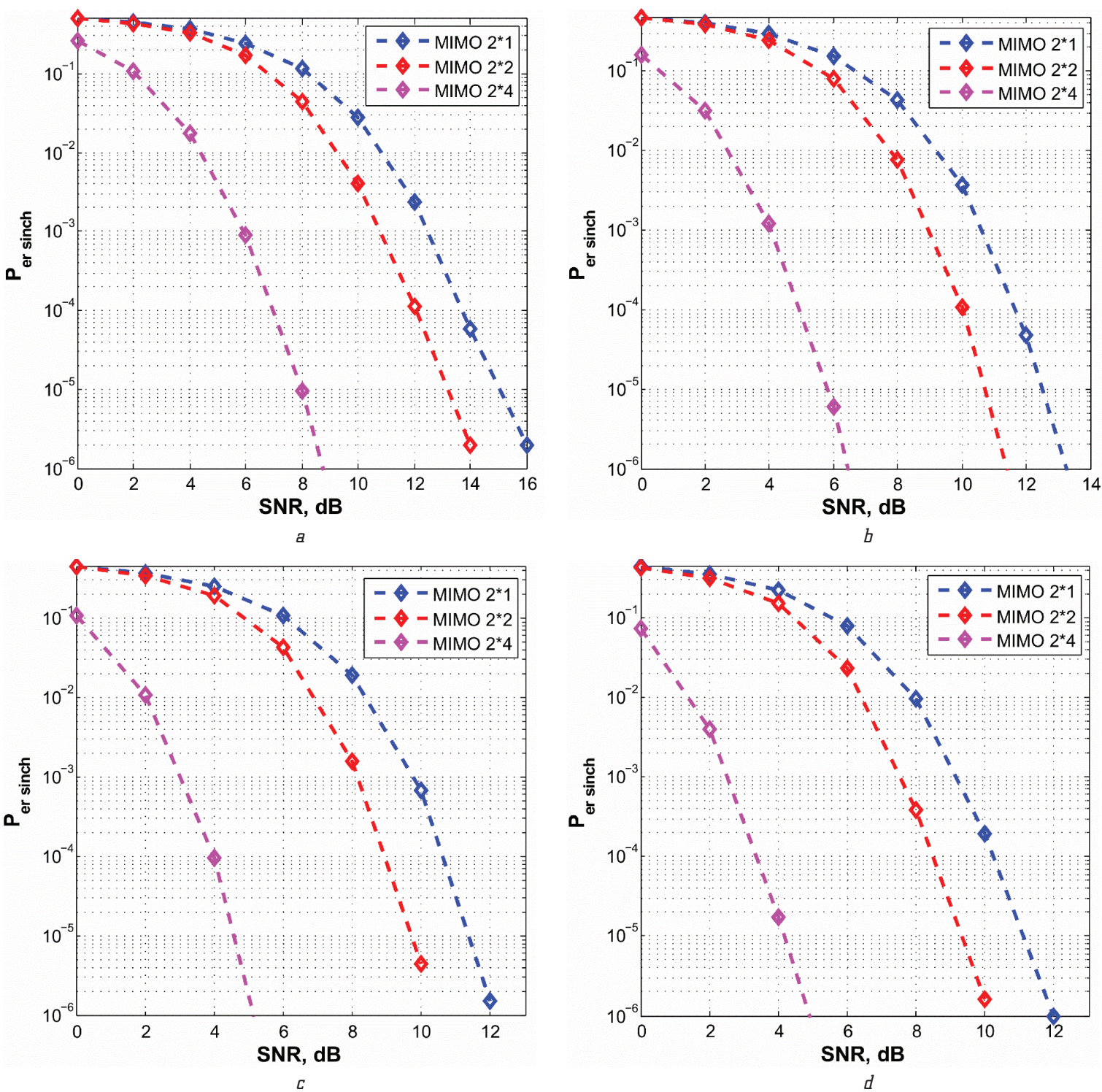

Fig. 1. Dependencies of $P_{e r \_s i n c h}$ on SNR for various amounts of $\mathrm{N}$ at QPSK: $a-$ at $K=10 ; b-$ at $K=20 ; c-$ at $K=30 ; d-$ at $K=40$
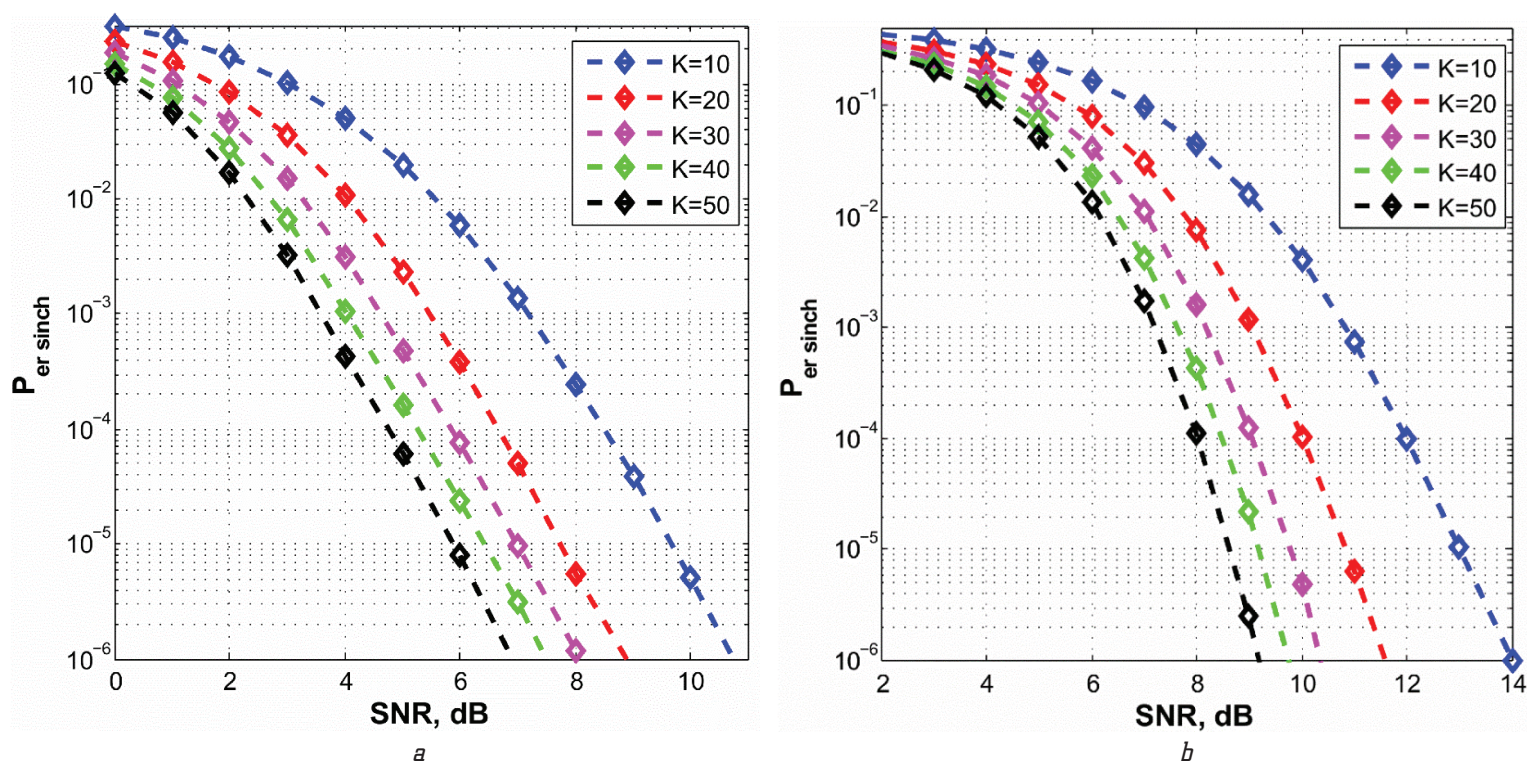

Fig. 2. Dependence of $P_{e r \text { sinch }}$ on SNR at $K=10 ; 20 ; 30 ; 40 ; 50$, MIMO $2 \times 2: a-$ at BPSK; $b$ - at QPSK 
4) when analyzing the dependences of the probability of the exit from synchronism $\left(P_{\text {er sinch }}\right)$ (Fig. 1, 2) and the probability of error of the received bits (BER) [1, Fig. 6] it is possible to conclude that the developed synchronization algorithm is more noise-resistant than the DSTBC method. Example: at QPSK, MIMO $2 \times 2, K=10 ; 20$; 30; $40,-P_{\text {er sinch }}$ less than BER by $5 ; 7 ; 8.3$ and $8.5 \mathrm{~dB}$, respectively.

\section{Conclusions}

The blind frame synchronization algorithm proposed for this work for the DSTBC method [1] is the first consideration of the blind frame synchronization for STBC differential orthogonal systems. This algorithm has advantages over similar algorithms in the required number of frames to ensure synchronization and computational complexity, as well as being flexible for extensions. The simulation results confirm its ability to establish frame synchronization under the condition of a low signal-tonoise ratio in the system and the absence of the need for knowledge about the state of the communication channel.

\section{References}

1. Tokar, M. S. (2018). Differencialnii metod blokovogo kodirovaniia dlia primeneniia v sistemakh MIMO. Sistemy sinkhronizacii, formirovaniia i obrabotki signalov, 1, 147-159.

2. Meyr, H., Moeneclaey, M., Fechtel, S. (1998). Digital communication receivers, synchronization, channel estimation, and signal processing. John Wiley \& Sons, Inc., 827. doi: http:// doi.org/10.1002/0471200573
3. Rohde, U., Whitaker, J., Zahnd, H. (2017). Communications Receivers: Principles and Design. McGraw-Hill Education, 941

4. Fomin, A. I. (2008). Sinkhronizaciia cifrovykh radiosistem peredachi informacii. Moscow: SAINS-PRESS, 80.

5. Blahut, R. E. (2010). Modem Theory: An Introduction to Telecommunications. Cambridge University Press, 515. doi: http:// doi.org/10.1017/cbo9780511811401

6. Nasir, A. A., Durrani, S., Mehrpouyan, H., Blostein, S. D. Kennedy, R. A. (2016). Timing and carrier synchronization in wireless communication systems: a survey and classification of research in the last 5 years. EURASIP Journal on Wireless Communications and Networking, 2016 (1), 180-218. doi: http:// doi.org/10.1186/s13638-016-0670-9

7. Mahmood, A., Ashraf, M. I., Gidlund, M., Torsner, J., Sachs, J. (2019). Time Synchronization in 5G Wireless Edge: Requirements and Solutions for Critical-MTC. IEEE Communications Magazine, 57 (12), 45-51. doi: http://doi.org/10.1109/ mcom.001.1900379

8. Volkov, L. N., Nemirovskii, M. S., Shinakov, Iu. S. (2005) Sistemy cifrovoi radiosviazi: bazovye metody $i$ kharakteristiki. Moscow: Eko-Trendz, 392.

9. Marey, M., Dobre, O. A., Inkol, R. (2013). A Novel Blind Block Timing and Frequency Synchronization Algorithm for Alamouti STBC. IEEE Communications Letters, 17 (3), 569-572. doi: http://doi.org/10.1109/lcomm.2013.13.122518

10. Marey, M., Dobre, O. A., Liao, B. (2014). Second-Order StatisticsBased Blind Synchronization Algorithm for Two Receive-Antenna Orthogonal STBC Systems. IEEE Communications Letters, 18 (7), 1115-1118. doi: http://doi.org/10.1109/lcomm.2014.2323245

Tokar Mikhail, Postgraduate Student, Department of Theory of Electrical Communications, O. S. Popov Odessa National Academy of Telecommunications, Ukraine; Senior Lecturer, Department of Quantum Radiophysics and Communication Systems, Taras Shevchenko Transnistria State University, Moldova, Tiraspol, ORCID: http:// orcid.org/0000-0002-1063-7940,e-mail: himmler250884@gmail.com 